POST-COMMUNIST ECONOMIES (1463-1377 1465-3958) - Megjelenés alatt

Digital transformation - enabling factory economy actors' entrepreneurial integration in global value chains?

Andrea Szalavetz*

Institute of World Economics, Centre for Economic and Regional Studies (KRTK)

Address: Tóth Kálmán utca 4, Budapest, Hungary, H-1097

E-mail: aszalave@gmail.com 


\section{Digital transformation - enabling factory economy actors' entrepreneurial integration in global value chains?}

Drawing on interviews with ten Hungarian digital automotive technology providers, this paper investigates how digital transformation can assist factory economy digital entrepreneurs in their integration in the highly concentrated automotive global value chains (GVCs).

We identified four mechanisms by which digital transformation can, in principle, produce opportunities for factory economy actors' entrepreneurial integration in automotive GVCs, as follows. (1) New entrepreneurial opportunities in the digital realm; (2) Fineslicing innovation and globalization of $\mathrm{R} \& \mathrm{D}$; (3) Ecosystem-type innovation collaboration; (4) Interaction-intensity of custom-tailored digital services provision.

However, to realize the potential of these opportunities, a critical mass of capable digital entrepreneurs needs to be achieved: a long way to go for factory economies.

Keywords: digitalization; digital entrepreneurship; integration in global value chains; automotive industry; high-road development; upgrading.

\section{Introduction}

In an era when the world economy is experiencing a profound structural change driven by technological progress, it is increasingly challenging for dependent, factory economies ${ }^{1}$ to sustain the momentum of their FDI-driven upgrading, create additional and better jobs, and reduce the productivity gap with advanced economies.

The slowdown in global FDI (UNCTAD, 2018) coupled with a consolidation of global value chains (GVCs) results in factory economy actors' increased difficulties in getting integrated in GVCs. Factory economy actors are striving to survive and remain competitive amidst rising concentration of industries and markets (Bajgar et al., 2019; Bessen, 2017; De Loecker and Eeckhoout, 2018). The falling trade in intermediate goods (Georgieva et al., 2018) indicates, among others, that lead companies are streamlining their supplier base and limiting their transactions to a smaller-than-before number of large and capable suppliers (Lee and Gereffi, 2015; Parrilli and Blažek, 2018). 
Most observers subscribe to the view that this gradual, albeit unabated structural change in GVCs is closely associated with the digital transformation of industries and businesses.

Factory economy actors, among others, actors from the Central and Eastern European integrated periphery (Pavlínek, 2017) are bound to face two adverse effects of digital transformation. One is advanced economy producers' slowing offshoring rate (De Backer et al., 2018). With increasingly sophisticated labor-saving technologies (e.g. the robotization of new processes that used to require human dexterity), the inflow of new greenfield investments slows down (Galgóczi et al., 2015). Consequently, the impetus of GVC integration-driven catching up, referred to by Parrilli and Blažek (2018) as a 'cascade' effect, ${ }^{2}$ weakens. Selection mechanisms gain momentum, and lead companies reconfigure their global networks, ${ }^{3}$ which intensifies inter-subsidiary competition.

A related adverse development may come forth as a consequence of the newly installed, fully automated, smart manufacturing capacities in advanced economies. Digital technologies enable advanced economy producers to manufacture higher quality goods, at lower prices, and closer to customers (for anecdotal evidence see e.g. Biesheuvel, 2017, Wiener, 2017). In that case, demand for factory economies' existing, previously offshored, and relatively obsolete production capacities declines.

According to Hallward-Driemeier and Nayyar (2017), as a consequence of digital technology adoption, there will be fewer entry points in GVCs. Factory economy suppliers will be able to maintain their existing production responsibilities only if they fulfil higher requirements in terms of production capacity, functional capabilities, (digital) infrastructure, and local supplier base than previously. Higher operational efficiency, and upgraded functional capabilities enabled by digital technologies have become the norm for survival. Blažek et al. (2018) and Pavlínek and Žižalová (2016) provide a number of real-world examples of suppliers forced to exit GVCs because they failed to upgrade and meet higher-than-before requirements. 
POST-COMMUNIST ECONOMIES (1463-1377 1465-3958) - Megjelenés alatt

Considered from a macro-perspective, these incidents weaken the development prospects of dependent market economies whose modernization has long relied on efficiencyseeking FDI in manufacturing (Hallward-Driemeier and Nayyar, 2017; Nölke and Vliegenthart, 2009).

These arguments are, however, in sharp contrast with the predicted developmental impact of digital transformation (e.g. Kagermann et al., 2013; Manyika et al., 2013; Schwab, 2016). The deployment of advanced digital manufacturing technologies improves local production capacity, and helps FDI hosting factory economies achieve higher productivity, improve operational excellence, and maintain thus their attractiveness to prospective efficiencyseeking foreign investors. Moreover, Szalavetz (2019) argued that digital technology implementation improves not only local production capabilities but it contributes also to the upgrading of subsidiaries' technological and R\&D capabilities, by enabling the decentralization of corporate technological and $\mathrm{R} \& \mathrm{D}$ activities.

However, following the 'golden era of FDI' (Galgóczi et al., 2015), the digitalizationdriven upgrading of global companies' existing manufacturing subsidiaries will hardly compensate for the decline of efficiency-seeking FDI inflows. Consequently, new sources of growth, development, and upgrading will prove more important than previously.

This paper investigates whether digital entrepreneurship could act as a driver of economic upgrading in dependent market economies, whose growth and modernization has so far depended almost exclusively on efficiency-seeking FDI inflows in manufacturing (Nölke and Vliegenthart, 2009).

Digital entrepreneurship is defined as the setting up of entrepreneurial ventures with offerings (products, services or product-service systems) that embody, or are embodied in or enabled by digital technologies (Lyytinen et al., 2016). We argue that the provision of digital solutions and services may become a channel for local companies' entrepreneurial integration 
in GVCs. Consequently, digital transformation has the potential to assist factory economies in progressing towards a high-road trajectory of economic development.

The context of this study is Hungary, a typical dependent market economy (Farkas, 2011, 2016), where both innovation performance (European Innovation Scoreboard, 2018) and business digitization performance are particularly weak: according to the business digitization index, ${ }^{4}$ Hungary scores the second lowest in EU28, preceding only Romania (DESI, 2018). ${ }^{5}$ Hungary's position in international rankings of entrepreneurial capabilities and performance ${ }^{6}$ and of digital entrepreneurship ${ }^{7}$ is worse than what its development level would suggest.

Even in such a 'low/moderate-performer' country, observers find it relatively easy to identify a couple of tech start-ups, and high-flying, entrepreneurial companies in nascent industries. These companies leverage their technological capabilities for independent and highprofit integration in GVCs. Although their experiences cannot be generalized into optimistic macroeconomic conclusions, the insights derived from the analysis of their cases can offer an answer to our research question.

RQ: How can digital transformation facilitate factory economy actors' entrepreneurial integration in global value chains?

In addressing this question, we take a micro-perspective, and explore the profiles of a sample of Hungarian digital entrepreneurs and the features of their GVC integration. We delve into the multiplicity of cyber technologies-driven opportunities exploited by factory economy actors for their entrepreneurial integration in GVCs. Investigation of these specifics helps us validate the proposition that digital entrepreneurship can support factory economies' progress towards a high-road trajectory of economic development.

The industry context is the automotive industry, which is a good choice for three reasons. Firstly, Hungary, just like its Central and Eastern European counterparts, is an important regional cluster of the global automotive industry (Pavlínek, 2017; Sturgeon et al., 
2008). In Hungary, the automotive industry is dominated by foreign-owned manufacturing units, subsidiaries of global original equipment manufacturers (OEMs) or of their global suppliers. This industry accounted for more than a quarter (27.1\%) of total manufacturing production in $2018 .^{8}$ From another perspective, the excessive weight of the industry makes these countries exposed to the developments in the automotive industry and to lead companies' strategic decisions.

The second reason is that in the digital age, the physical end-products of this industry (the vehicles) have become platforms for complementary digital offerings. The importance of these offerings keeps increasing, since they serve as differentiating factors influencing the competitiveness of the end-products. The attraction and the retention of car buyers is increasingly determined by the quality and range of embedded digital services. More importantly, the creation of complementary digital offerings is not necessarily internalized by OEMs, which creates numerous entrepreneurial opportunities for new technology-based firms (Autio et al., 2018a; Porter and Heppelmann, 2014).

The third reason is that in automotive value chains the digital intensity of value adding activities is one the highest of all industries (Calvino et al., 2018). Automotive companies are pioneering digital technologies also in their production processes, since quality, safety and product traceability requirements have long required computerization, automation, implementation of sensors, and access to and storage of a variety of production data. Although some global automotive companies develop and implement production-supporting digital solutions in-house, as it will be shown, the integration of digital solutions in the production systems of local manufacturing subsidiaries often represents business opportunities for local solution providers.

In the following sections, we first briefly summarize the recent disruptive developments in the automotive industry, and review the received literature on the impact of digital 
POST-COMMUNIST ECONOMIES (1463-1377 1465-3958) - Megjelenés alatt

transformation on entrepreneurial opportunities. Following the literature review, the method of empirical data collection is outlined, and the sample of the interviewees introduced. Subsequently, the empirical findings are presented. The final sections provide discussion, and elaborate on the policy implications and limitations of our results.

\section{Overall transformation in the automotive ecosystem}

Research for this study was conducted in a 'Cambrian moment' of the automotive industry (Ferrás-Hernandez et al., 2017). This previously stable, oligopolistic and mature industry is experiencing unprecedented instability, with radical innovations transforming the distribution of value added along the value chain. Market turbulence is also enhanced by numerous new entrants from other industries, who capitalize on the fading boundaries of the automotive industry, and reconfigure competition through service-based offerings (Gao et al., 2016). Just like in the early phase of the industry lifecycle, a fierce competition started for dominant design: this time, with respect to the powertrain (electric vehicles, hydrogen fuel cells, etc.), operation (connectivity, autonomous driving), and business model (shared mobility, mobility as a service - Kaiser et al., 2017).

Digital offerings are proliferating in the field of infotainment, navigation, fleet tracking, driving assistance systems, cyber security, and so forth. These offerings account for an increasingly large share of the total value added, calling the producer-driven governance of automotive value chains into question (Kuang et al., 2018). Additionally, some radical innovations are expected to transform also the downstream functions in the value chain, such as distribution (digital marketplaces) and aftersales services (e.g. remote maintenance, 3D printing).

Although the end-products (vehicles) represent the most conspicuous manifestation of digital transformation in the automotive industry, digital technologies are ubiquitous also in the 
automotive production systems. Reshaping their traditional processes, manufacturers (automotive OEMs) integrate cyber-physical systems in their production and logistics systems, connecting the physical components of the system with the advanced analytics of real-timecollected production data. The cyber components provide feedback to and enable real-time control of and interventions in complex production systems. The smart and connected core, the cyber-physical production system (cf. Monostori et al., 2016) integrates a large number of digital solutions supporting or automating production related business processes, for example, solutions associated with the digital twin of products and the production system, empowering simulations (as parts of product and process development) and virtualization (e.g. virtual commissioning), and solutions related to resource optimization and predictability.

Altogether, these developments substantiate Hill et al.'s (2014) call for (re)classifying the automotive industry as a high-technology one (see also, Hirsch-Kreinsen and Schwinge, 2014; Mendonça, 2009).

\section{Digital technologies facilitating local actors' knowledge-based, entrepreneurial integration in global value chains}

Digitalization is considered to herald a new era in entrepreneurship (Nambisan, 2017), significantly augmenting entrepreneurial opportunities. Cyber technologies foster entrepreneurship, and help domestic-owned digital entrepreneurs integrate in GVCs by reducing entrepreneurship-related costs and facilitating new forms of value creation.

For example, digital technologies reduce the costs of market entry, either by promoting disintermediation, that is, by enabling direct interaction with end-users, or by permitting entrepreneurs to gain access to global markets through digital platforms ${ }^{9}$ (Autio et al., 2018a; Sussan and Acs, 2017). Additionally, technologically competent entrepreneurs can access ICTrelated capital assets and services through cloud computing (e.g. Ross and Blumenstein, 2015) 
and through various 'as-a-service' offerings, which significantly lowers the upfront capital investment requirements of their activities. Technology entrepreneurs can leverage the interactivity and the network effects of the digital communication landscape for information acquisition and dissemination. Web 2.0 solutions, such as blogs and social media reduce the costs of building reputation and of strategic positioning in the market (Stankovska et al., 2016).

Digital technologies-driven cost reduction for entrepreneurial initiatives is manifested also in another digital transformation-specific domain, in the so-called 'lean start-up' mode of market-entry (Blank, 2013; Ries, 2011), defined as market entry without a long and large-scale upfront development of the offerings. Lean start-ups would launch 'minimum viable products': offerings that are intentionally incomplete (Nambisan, 2017), and rely on customers' feedback for further development. This permits a low-cost experimentation with entrepreneurial ideas (Autio, 2017; Autio and Cao, 2019).

Digitalization fosters entrepreneurship, and assists local entrepreneurs in their integration in GVCs also by enabling new forms of value creation. The diversity, complexity, and value of digital solutions enhancing the functionality of products are on par with those of digital solutions integrated in production systems.

Note that there is more to the digital basis of value creation than the millions of lines of codes embedded in production systems and in end-products. The digital bedrock consists of an immensely complex set of technologies that contribute to developing digitally enhanced products, harnessing digitally mature production systems, and nurturing digitally mature businesses.

Consider the example of production systems. The information systems of manufacturing plants integrate an exponentially growing number of diverse applications and solutions that together, form an ecosystem of manufacturing services. Part of these services automate manufacturing-related and back office activities, for instance quality control, fault diagnosis, 
process documentation, and inventory management. Other digital manufacturing services support operations-related decisions, for example, production planning and scheduling, and enable resource optimization. Yet other smart services embedded in the information system support business management and strategic decision-making, e.g. through custom-tailored business intelligence solutions that identify, visualize, and address particular business processspecific problems, suggest actions, and predict opportunities.

Digital manufacturing services supporting either operations and related back office functions or business management rely on complex technology stacks encompassing data extraction, data processing, and analytics, and solutions ensuring connectivity, communication, cyber security, and system integration (Chen et al., 2012, Zeid et al., 2019).

The individual components of this immensely complex information system may all be sourced from different technology providers. Consequently, innovative start-ups specialized in the provision of operations-related digital services, together with the ones providing product life cycle support through digital twin technologies, and the ones specialized in productenhancing digital functionalities may harness myriad opportunities to become integrated in GVCs.

The diversity, complexity, and the distributed character of the underlying digital technologies have mitigated the reluctance of incumbent OEMs and Tier 1 suppliers to open up their innovation processes. OEMs are abandoning their traditional strategy of vertically integrated $R \& D$, and exploit new sources of added value by pursuing an 'innovation ecosystem strategy' (Nambisan et al., 2017), to ensure access to new technologies and capabilities (CanoKollmann et al., 2018). Committed to collaborate with third-party developers and nontraditional industry participants, OEMs integrate increasingly diversified and fine-sliced knowledge inputs. This presents numerous entrepreneurial opportunities for new technologybased start-ups (Autio et al., 2018a). 
POST-COMMUNIST ECONOMIES (1463-1377 1465-3958) - Megjelenés alatt

\section{Research design, data collection and analysis}

Since the developmental impact of digitalization is a highly contested issue, and digital entrepreneurship by domestic-owned actors in factory economies is a nearly uncharted territory of academic research (Szerb et al., 2018), this paper employs an exploratory research design, combining desk research and interview-based research (Eisenhardt, 1989).

In order to explore the drivers and enablers of automotive technology-oriented digital entrepreneurs' integration in global value chains, we first mapped the Hungarian automotive technology ecosystem. To do so, we relied on the author's proprietary database of a collection of business press and technology press articles. Articles reporting either on the digital transformation of Hungarian companies or on Hungarian digital entrepreneurs have been collected from a variety of sources, including www.techmonitor.hu, www.gyartastrend.hu, www.autopro.hu, www.hwsw.hu, www.computerworld.hu, and www.itbusiness.hu, and automotive technology companies identified. This mapping exercise was also facilitated by the membership of the author's institution in the Industry 4.0 National Technology Platform (the author being one of the contact persons) and in the (Hungarian) Artificial Intelligence Coalition. Membership provided the author an invaluable stream of information about digitalizationrelated developments and key actors in Hungary.

Our mapping exercise yielded a sample of 22 companies. Applying the method of purposeful sampling (Patton, 1990) we chose ten companies whose cases seemed promisingly information rich for interview-based investigation. We focused on domestic-owned digital technology-based firms, and excluded the companies that had been taken over earlier by foreign investors. The local subsidiaries of global digital technology providers were also excluded.

Figure 1 shows the results of our mapping exercise. Interviews were conducted with technology providers represented by blue circles. ${ }^{10}$ Figure 1 substantiates the long noticed multi-invention setting, in which automotive OEMs operate (see e.g. Somaya et al., 2011). 


\section{Figure 1 around here}

Figure 1 demonstrates that we could identify domestic-owned companies in most $^{11}$ of the technological areas that are currently associated with the digital transformation of the automotive industry.

Next, we collected and reviewed secondary source data on these companies, specifically, qualitative information from their websites and from press articles, and basic corporate performance indicators (year of foundation, turnover, employment) from publicly available profit and loss statements. Qualitative information was gathered about the particularities of the technology developed by these companies, focusing on use cases describing the application of the given solutions. Additionally we reviewed their references, i.e. the list of their major customers.

Our face-to-face interviews were also organized around these questions (technology specifics and customers), and were complemented with inquiries about the history of the venture, the market development and GVC integration strategy, and the network of business partners.

Accordingly, the mechanisms by which digital transformation can facilitate factory economy actors' entrepreneurial integration in global value chains were identified through an indirect method of assessment (Achcaoucou et al., 2014). Rather than asking our informants to evaluate whether and how digital transformation can foster their integration in automotive value chains, they were asked to describe the market orientation of their ventures, and the obstacles and enablers of business development. Regarded as holding the key to answering our research question, these insights were analyzed by means of inductive research, as detailed below.

Interviews lasted 90 minutes on average, and were conducted between January and April, 2019. We compiled detailed descriptions of each case, and conducted the analysis using standard within-case and cross-case analysis techniques (Eisenhardt 1989). Interviewees' 
remarks, combined with insights obtained from written records, were considered raw data. Our first analytical exercise was a thematic analysis, aimed at grouping raw data by common patterns (first order coding). We applied the constant comparative method for data analysis (Glaser, 1965), collecting and analyzing data simultaneously. This allowed us to cross-check the emerging patterns in subsequent interviews, and/or contrast interviewees' remarks with the ones gained in prior interviews.

At a later stage of the analysis, these first order codes were used to extract theoretical categories from, as suggested by Gioia et al. (2013). We continued this data reduction exercise, turning the theoretical categories into more aggregate concepts of 'mechanisms' by which digital transformation can assist factory economy actors in their entrepreneurial integration in GVCs. This data analysis procedure is illustrated in Table A in the Annex.

Although delving into micro-level phenomena to understand macro-level developments is an accepted approach in social sciences (Barney and Felin, 2013; Raub et al., 2011) since it often generates deeper and closer-to-real-world insights than what focusing exclusively on macro-level indicators would generate, the small and biased sample (consisting of successful entrepreneurial ventures) requires a caveat: our findings are by no means generalizable. However, the insights obtained from the analysis of the surveyed sample and from the interviews do serve as illuminative illustrations of our arguments.

\section{Results}

\section{Profile and particularities of the technology}

The working assumption we adopted in this study was that the emergence of new digital processes supporting production and business activities, together with a plethora of new product-service combinations will expand the opportunities of digital entrepreneurship, even in peripheral regions. 
Consequently, as a first step of our research, we explored the particularities of the surveyed entrepreneurs' offerings. Table 1 provides a detailed description of the areas where the surveyed entrepreneurs perceived opportunities for developing digital offerings, together with some basic characteristics of the firms in the sample.

\section{Table 1 around here}

Figure 1 and the detailed descriptions in Table 1 highlight that the offerings of the sample companies show a great diversity, reflecting the multiplicity of entrepreneurial opportunities stemming from new digital product-service combinations. The composition of the offerings is similar to that of the companies in the broader database (of the 22 Hungarian-owned digital technology-based companies in the automotive ecosystem).

The majority of the companies in both samples are specialized in production-related digital solutions, with higher or lower hardware content. Product-service systems with relatively higher hardware content include factory automation and robot integration services, or design and deployment of special-purpose machinery equipped with data extraction and processing solutions, RFID-based real-time tracking of assets, and process \& condition monitoring solutions. Other services, supporting various production-related business functions and operations-related decisions, are mainly or uniquely software-based. Examples include visualization (e.g. of overall equipment effectiveness), production scheduling, predictive maintenance, system testing, and production-related engineering services, such as simulation or virtual commissioning ${ }^{12}$.

A relatively smaller share of the companies in both samples specialized in digital services supporting business management. Examples include robotic process automation, i.e. automation of repetitive and routine task-intensive business processes, custom analytics, and business intelligence services provision. 
POST-COMMUNIST ECONOMIES (1463-1377 1465-3958) - Megjelenés alatt

We could identify some companies in both samples that were core technology providers, whose solutions were embedded in automotive products, specialized, for example, in autonomous driving technology, connected vehicle technology, navigation solutions, cyber security solutions. Finally, in the broader sample, there were some mobility-related technology providers, specialized in telematics-based smart insurance technology, fleet management technology, or in mobility-as-a-service solutions.

\section{Market orientation}

Both the interview data and secondary source information confirmed the claim that digital entrepreneurs are industry agnostic (Autio and Cao, 2019): their solutions can be used by customers in any sector. Although the solutions and the capabilities of most of the surveyed firms are not industry-specific, and consequently their customer portfolios are not limited to automotive industry actors, automotive companies represent a large share of the customers. This demonstrates the pioneering status of the automotive industry in the field of digital transformation.

The composition of the surveyed firms' customers is more or less determined by the specifics of their offerings. Companies with production-related solutions or solutions supporting production-related business functions target mainly Hungary-based manufacturing firms - these are usually the local subsidiaries of global companies. By contrast, the companies developing automotive-related core technology (product-embedded digital services, such as No. 1 and 3) were export-oriented.

No. 4 explained its global orientation with the 'push factor' of internationalization, claiming that Hungarian customers, including the subsidiaries of global companies are too cautious to become the first customers of highly innovative technologies. 
POST-COMMUNIST ECONOMIES (1463-1377 1465-3958) - Megjelenés alatt

Furthermore, the low-cost location status of Hungary results in local firms' insufficient readiness for industry 4.0 technologies - this applies not only to the majority of domestic-owned companies, but also to some of the local subsidiaries of global companies. This 'push factor' would also prompt smart factory solution providers to acquire international customers. As a manager interviewed explained:

"Customers start negotiating with us about the ways and means of deploying industry 4.0 solutions. However, our screening reveals that, in reality, they have industry 3.0 problems. We start to eliminate the major bottlenecks, and make them ready to adopt and assimilate our upto-date digital solution. This is a long process, and it diverts us from concentrating on the diffusion and customer feedback-driven further development of our own technology."

Notwithstanding, our informants unanimously maintained that their existing Hungary-based customers are the local progressive pioneers of digital transformation. They are sophisticated and demanding customers, consequently, services provision contributes to providers' learning and capability accumulation (Porter, 1990).

When asked about their market development strategy, somewhat counter-intuitively, the providers of production-related digital services emphasized that in several instances, would-be customers made the first step, requesting for a quote. Local manufacturing subsidiaries were looking for technology providers capable to solve their technical or business problems. Some of the managers interviewed (No. 5, 6, 7, 8) have explicitly underscored that there is such a high demand for their specialized expertise in digital engineering services provision that they do not have to make substantial investments in business development: they have even more assignments than what they could reliably accomplish.

Business expansion within Hungary was also facilitated by manufacturing subsidiaries' quest for localization, that is, for the local procurement of production related smart solutions. 
POST-COMMUNIST ECONOMIES (1463-1377 1465-3958) - Megjelenés alatt

"You know, when a local manufacturing subsidiary specializing in relocated production activities is established, except for the workforce, practically every component of its activity is foreign (relocated). The gradual localization of inputs starts later, once interventions in the production system are required. For example, the expansion of production or the introduction of new products may require the integration of new machinery, and the adaptation of the IT system. Any kind of intervention or process upgrading induces technological problems. This is a window of opportunity for us, since the management of these manufacturing subsidiaries quickly realizes that it is easier and much cheaper to source custom-tailored technical knowledge locally than to rely on parent companies' technical assistance. The situation is similar when it comes to increasing the digital maturity of the customers' production facilities. Our proposed smart solutions are effective only if we define the problems to be solved together with the customer, and we establish the key performance indicators to be achieved also jointly."

Over and above cost advantages, reliance on local services providers is sensible also because of the interaction-intensity of digital services provision. Defining the problems, determining the data requirements, coping with process challenges, and implementing the digital solution requires long 'joint development work' with multiple feedback loops between the teams of the services provider and that of the contractor.

Relatedly, some of our informants noted that in addition to digital technologies-related skills and expertise, such as software development and engineering skills, familiarity with machine learning, modelling, simulation, and cyber security-specific expertise, it is imperative to possess also domain-specific (e.g. automotive) knowledge in order to understand the needs and the technical problems of customers. 
POST-COMMUNIST ECONOMIES (1463-1377 1465-3958) - Megjelenés alatt

"Understanding and codifying customers' problems is one of the most difficult parts of the project development process, since customers themselves often fail to properly define or specify their own problems."

If a local digital solution provider manages to 'get behind the fence' and is entrusted by a local subsidiary of a global company to propose, develop, and implement a solution of a particular technological problem, or carry out a partial digital transformation project, he can rightly expect that assignments would later grow in size and complexity. This kind of solution provision is not a one-off activity, just the contrary. A common feature of manufacturing companies' investments in digital transformation is that the first projects are usually followed by broadening and deepening assignments, if the solutions of the technology providers prove to be effective.

Effective solution provision may also lead to indirect export. In several instances, the solutions implemented at the local manufacturing subsidiaries of global automotive companies proved so successful that the mother companies decided to deploy the same solution at several subsidiaries in other countries.

\section{Strategic alliance partners facilitating GVC integration}

One conspicuous commonality that crystallized from the interviews was that the GVC integration of export-oriented firms (No. 1, 2, 3, 4), of new start-ups (No. 10), and of some other firms in the sample was facilitated by strategic alliance partners. In the case of firms with science-based offerings, consortium partners in international research projects (e.g. Eureka, Horizon2020), or in pilot demonstration projects played a key role in business development. No. 1 and 3 participated in dozens of demonstration projects across three continents, where autonomous and/or connected vehicles were tested in the real-world environment of cities. In addition to transportation authorities and municipalities, project partners would include large 
POST-COMMUNIST ECONOMIES (1463-1377 1465-3958) - Megjelenés alatt

OEMs, research institutes, software providers, unit providers (e.g. on-board and roadside units), and sensor providers - each contributing specific knowledge inputs.

"We collaborate with a broad range of actors, who may eventually integrate our solutions in their products. I would describe our connections as a kind of voluntary co-specialization. However, since we collaborate with several potential partners, this kind of co-specialization engages our partners without limiting our entrepreneurial opportunities."

Some of the suppliers of the companies interviewed represent yet another type of strategic alliance partner, fostering their GVC integration. For example, reliance on global software products for digital services provision (e.g. software packages supporting big data analytics, or computer-aided engineering) proved an invaluable means for the GVC integration of No. 2, 6, and 10 .

No. 2, the business intelligence services provider, relies on a globally used software product for data visualization. The U.S. owner of this software product regularly organizes workshops or webinars for its community of users, clarifying selected features of the software, and presenting use cases. This was a good opportunity for No. 2 to demonstrate its capabilities, present case studies, get access to community members, and find new business partners. Endorsed by the prestigious U.S. software company, that recommended No. 2 to some of its own Fortune 500 customers, some of these blue chip companies pivoted to entrust No. 2 to develop business intelligence solutions that solve their specific problems. Once they could assess the quality of No. 2's technological capabilities, the Fortune 500 companies have gradually increased the depth and breadth of their assignments, which allowed for extraordinary rapid growth of the Hungarian services provider.

No. 6 and 10 reported about similar mechanisms. No. 6 uses another global software product for simulation and finite element analysis, for developing its own custom-tailored services. No. 10's solution is presented in the 'solution galleries' of its strategic alliance 
partners, a U.S. software company and a U.S. hardware and system integrator company, which boosted the credibility and the reputation of the Hungarian start-up, and generated new business opportunities.

Distribution and service agreements with machinery companies triggered similar developments in the case of No. 5. The global providers of the machinery encapsulated in No. 5's complex solution would broker some business deals for this company, which proved to be a good reference both for later assignments by the same customers, and for attracting new customers.

Altogether we found that the offerings of the surveyed firms were either components of complex digital solutions or they were the ones that integrated knowledge inputs developed by third parties in their own digital solutions. In any case, they are integrated in a network of suppliers, distributors, technology providers, collaborators, and strategic partners. 'Ecosystem partners' would not only provide complementary components of knowledge, or integrate these components into a complex solution, they would also bring in additional business opportunities for their ecosystem partners.

\section{Discussion}

Following the descriptive analysis of our results, it is time to return to our research question. What justifies the claim that digital transformation can facilitate the entrepreneurial integration of domestic-owned digital technology-oriented ventures in peripheral factory economies in the highly concentrated automotive value chains?

Our results point to four mechanisms by which digital transformation enabled the entrepreneurial integration of the surveyed domestic-owned companies in automotive GVCs. (1) Digital transformation generated an array of new business opportunities by transforming the product-based value chains themselves. It reinforced the softwarization of both operations and 
management, together with the servitization of products (consider the myriad of new servicesbased offerings related to the end products). The emerging huge and continuously expanding digital technology stack supporting GVC activities or embedded in the end products elicited new offerings and gave rise to new kinds of market linkages to be harnessed by digital entrepreneurial ventures.

(2) At the same time, digital technologies facilitated GVC actors' developing and deploying increasingly complex technology stacks and coping with complexity by supporting technological and organizational solutions that allow for innovation activities to become even more distributed than before. For example, digital tools empowered new forms of communication, knowledge sharing, and collaboration. They assist in establishing decentralised and networked forms of value creation, such as the fine-slicing of and crowdsourcing for innovation (cf. Majchrzak and Malhotra, 2013; Simula and Ahola, 2014). New, flexible forms of connectivity allow for innovative digital entrepreneurs to establish loose ties with incumbent lead firms (OEMs and Tier 1 suppliers) and engage in innovation collaboration. Altogether, the enhanced digital-intensity and complexity of value creation reinforced the globalisation of R\&D (Branstetter et al., 2019). While industries and markets have, indeed, become more concentrated than previously, innovation is becoming more distributed than ever.

(3) Collaborating partners, or in a broader sense, the ecosystem-type organization of both corporate digitalization projects and core technology generation projects proved to be important enablers of GVC integration for the surveyed companies. The complexity of the undertakings required the collaboration of diverse partners with complementary capabilities. Collaborating parties have learned about each other's resources and specific capabilities, which engendered later new business opportunities and access to partners' business communities for joint value creation and capture. 
(4) The fourth mechanism fostering the entrepreneurial integration of the surveyed companies in automotive GVCs is rooted in the interaction-intensity of production-related digital solution provision. The effective implementation of these solutions requires a close collaboration, at least, a series of interactions between technology providers and adopters. This prompted the automotive subsidiaries of global manufacturing companies to localize the procurement of customized digital solutions. Proximity to technology users became thus a source of competitive advantage for the surveyed companies. They have capitalized on the opportunities created by the interaction-intensity of production-related digital solution provision.

An important caveat is necessary here. Although several of these mechanisms have worked in the case of each company in the sample, assisting in their integration in global automotive value chains, most of them work only in principle: in theory, they offer outstanding opportunities for digital entrepreneurs in factory economies, but in reality, these opportunities are barely exploited.

The developmental outcomes of digital entrepreneurship, that is the implications of digital entrepreneurs for the dependent position of Central and Eastern European countries (CEE), investigated on the basis of interviews with a sample of companies operating in the Hungarian automotive technology ecosystem that partly overlaps the sample of this paper, was analyzed in a companion paper (Szalavetz, 2020). We found that the specifics of the surveyed digital entrepreneurs do not fully and unambiguously conform to those described in the literature. Their growth performance leaves a lot to be desired, and although they are innovative in a Schumpeterian sense, their offerings are only in few cases disruptive. Instead of a 'transformative impact', the solutions of most of the surveyed digital technology providers allow for technology adopters to perform their traditional core activities more efficiently than previously. Furthermore, contrary to the alleged rapid internationalisation of digital entrepreneurs, most of the surveyed companies remained local. More importantly, as argued 
also in the introductory section of this paper, there are few competent digital entrepreneurs. ${ }^{13}$ We argued that in the dependent market economies of CEE, the extent to which digital entrepreneurs generate economic gains is dwarfed by that of efficiency-seeking foreign direct investment in export-oriented manufacturing. Consequently, local digital entrepreneurs can currently hardly improve the dependent position of CEE economies: their number and economic impact are too small to bring about the required qualitative shift in the development trajectories of these countries.

Nevertheless, the cases of the surveyed companies should be recognized as examples of innovation-driven, high-local-value-added, entrepreneurial activity, which supports the claim that digital entrepreneurship can, in principle, assist dependent market economies in progressing towards a high-road trajectory of economic development.

The wording "progressing towards" refers both to the long way to go for dependent market economies to shift to a high-road trajectory and to the fact that digital entrepreneurship is currently a weak tool for enabling such a shift in these countries.

\section{Implications and limitations}

These results call for a reassessment of the development policy priorities and instruments in dependent market economies. They make it clear that more emphasis needs to be laid on fostering digital entrepreneurship as a driver of qualitative economic development and enabler of factory economy actors' integration in GVCs with high-margin activities.

The point of departure for policy is the promotion of business enterprises' digital transformation. Over and above promoting industrial competitiveness and technological upgrading through advanced manufacturing, this strategy may engender non-negligible knowledge spillovers and, as argued above, produce opportunities for local digital entrepreneurs to plug in GVCs with self-developed digital solutions. However, although the 
market for digital solutions supporting manufacturing production and production-related business functions is growing rapidly, it does not translate automatically into higher local entrepreneurial dynamics. Consequently, the key area where policy support is needed is the accumulation of both technological (digital) and entrepreneurial competencies.

Accumulating and mastering the latter competencies, specifically, the capabilities required to monetize inventions, turn ideas into a viable business, and scale-up the ventures may prove to be even more difficult for factory economy entrepreneurs than building up digital competencies. Consequently, in addition to supporting entrepreneurial universities (Etzkowitz, 2003), entrepreneurship education needs to be included in the curricula of universities, in particular, in the curricula of universities of technology.

The areas for policy intervention should not be limited to improving digital entrepreneurs' access to resources for growth. Policy-makers seeking to promote digital entrepreneurship need to develop a good understanding of the differences between the characteristics and the needs of digital entrepreneurs offering production-related digital solutions and tools (including the providers of solutions supporting production-related business functions, such as production scheduling, predictive maintenance) and those of entrepreneurs offering product-embedded or product-related digital solutions. ${ }^{14}$ Policy measures supporting manufacturing companies' investments in digital solutions and tools (e.g. cyber-physical systems, smart algorithms, cloud computing, data analytics), and encouraging foreign-owned manufacturing subsidiaries' tapping into local knowledge through industry-university collaboration and cluster building (cf. Götz, 2019; Götz and Jankowska, 2017) are more relevant for entrepreneurs specialized in the former type of offerings. By contrast, supply- and demand-side policy instruments fostering the commercialization and market uptake of new digital artifacts, ${ }^{15}$ and supporting digital entrepreneurs' international business development, 
scale-up, and access to finance are important dimensions of policy efforts in the case of entrepreneurs specialized in the latter type of offerings.

Two remarks may be pertinent here. Firstly, policy in factory economies, e.g. in Hungary, used to consider the promotion of industrial competitiveness and technological upgrading - e.g. through subsidy provision to manufacturing companies' investments in new machinery — closely related to the expansion of production capacity (tangible assets) and, most importantly, to job creation. By contrast, support to investment in digital technologies enables the expansion of production rather through efficiency increase, which does not necessarily lead to job creation, at least not directly. These programs increase the competitiveness (in terms of efficiency and operational excellence) of the recipients of policy support, and represent business opportunities for the local providers of digital solutions, thus, they can indirectly lead to the creation of additional and better jobs.

Secondly, the aforementioned policy measures need to complement and not substitute for previous policy efforts aimed at attracting FDI in manufacturing. As argued above, FDI continues to represent the main driver of economic performance in dependent market economies, while digital entrepreneurship, together with quality FDI (cf. Alfaro and Charlton, 2013) contribute to strengthening the quality aspects, e.g. the local knowledge-intensity, spillover intensity, and local value added share of development. Digital entrepreneurship is not an alternative to FDI: neither in terms of driving economic development nor in terms of driving digital transformation (cf. Götz, 2019). Policy should rather leverage the synergy effect between quality FDI and digital entrepreneurship in both respects.

Finally, some limitations of this study must be acknowledged. On one hand, the small size of the sample and the single-country / single-industry contexts of the analysis can only illustrate our arguments. As with all exploratory research, only a considerable extension of the reviewed empirical evidence may enhance the extent to which our results can be generalized. 
On the other hand, if new technology-based, high-growth, entrepreneurial ventures remain rare species in factory economies, digital entrepreneurship will by no means shift these countries to a high-road trajectory of economic development. To achieve statistical significance as an enabler of a high-growth development trajectory, a critical mass of capable digital entrepreneurs is indispensable. Further research could analyze how other dependent market economy cases compare. Scrutinizing cases where the density of digital entrepreneurs is higher than in Hungary and/or their scale-up performance is better could improve our understanding of how to achieve a palpable impact of digital entrepreneurs on the quality of development.

Another important avenue for future research is to investigate whether the composition of this sample of digital entrepreneurs, where the majority of the surveyed companies specialize in production-related digital services, reflects a dependent market economy-specific distribution of digital entrepreneurs. Accordingly, further research is required to determine whether digital entrepreneurs with product-embedded or product-related digital solutions represent a higher share of the total digital entrepreneurial ecosystem in advanced economies than in dependent market economies.

\section{References}

Achcaoucaou, F., Miravitlles, P., \& León-Darder, F. (2014). Knowledge sharing and subsidiary R\&D mandate development: A matter of dual embeddedness. International Business Review, 23(1), 76-90.

Ács, Z. J., Szerb, L., Lafuente, E., \& Lloyd, A. (2018). Global Entrepreneurship and Development Index, 2018. Cham: Springer.

Alfaro, L., \& Charlton, A. (2013). Growth and the quality of foreign direct investment. In: Stiglitz, J.E., \& Lin, J. Y. (Eds.) The Industrial Policy Revolution I. London: Palgrave Macmillan, pp. 162-204. 
POST-COMMUNIST ECONOMIES (1463-1377 1465-3958) - Megjelenés alatt

Autio, E. (2017). Digitalisation, ecosystems, entrepreneurship and policy. Perspectives into Topical Issues Is Society and Ways to Support Political Decision Making. Government's Analysis, Research and Assessment Activities Policy Brief, 20. Available at: https://www.researchgate.net/profile/Erkko_Autio/publication/321944724_Digitalisation_eco systems_entrepreneurship_and_policy/links/5a3a5eb5aca2728e698a9498/Digitalisationecosystems-entrepreneurship-and-policy.pdf

Autio, E., \& Cao, Z. (2019). Fostering Digital Start-ups: Structural Model of Entrepreneurial Ecosystems. In Proceedings of the 52nd Hawaii International Conference on System Sciences. Available at: https://scholarspace.manoa.hawaii.edu/bitstream/10125/59979/0539.pdf

Autio, E., Nambisan, S., Thomas, L. D., \& Wright, M. (2018a). Digital affordances, spatial affordances, and the genesis of entrepreneurial ecosystems. Strategic Entrepreneurship Journal, 12(1), 72-95.

Autio, D., Szerb, L., Komlósi, É., \& Tiszberger, M. (2018b). The European Index of Digital Entrepreneurship Systems. Publications Office of the European Union, Luxembourg, 2018, ISBN 978-92-79-91303-7, doi:10.2760/39256, JRC112439

Bajgar, M., Berlingieri, G., Calligaris, S., Criscuolo, C., \& Timmis, J. (2019). Industry Concentration in Europe and North America. OECD Productivity Working Papers, No. 18., Paris: OECD Publishing.

Baldwin, R. (2013). Global supply chains: Why they emerged, why they matter, and where they are going. In: Elms, D.K., \& Low, P. (Eds.) Global value chains in a changing world. Geneva: Fung Global Institute, Nanyang Technology University and WTO, pp. 13-60.

Barney, J. A. Y., \& Felin, T. (2013). What are microfoundations? Academy of Management Perspectives, 27(2), 138-155. 
POST-COMMUNIST ECONOMIES (1463-1377 1465-3958) - Megjelenés alatt

Bessen, J. E. (2017). Information technology and industry concentration. https://papers.ssrn.com/sol3/papers.cfm?abstract_id=3044730

Biesheuvel, T. (2017). How Just 14 People Make 500,000 Tons of Steel a Year in Austria. Available at: https://www.bloomberg.com/news/articles/2017-06-21/how-just-14-peoplemake-500-000-tons-of-steel-a-year-in-austria

Blank, S. (2013). Why the lean start-up changes everything. Harvard Business Review, 91(5), $63-72$.

Blažek, J., Natsuda, K., \& Sýkora, J. (2018). Entrance-exit dynamics of suppliers and the repercussions for reshaping the structure of GVCs/GPNs. European Planning Studies, 26(12), 2364-2386.

Branstetter, L. G., Glennon, B., \& Jensen, J. B. (2019). The IT Revolution and the Globalization of R\&D. Innovation Policy and the Economy, 19(1), 1-37.

Calvino, F., Criscuolo, C., Marcolin, L., \& Squicciarini, M. (2018). A taxonomy of digital intensive sectors. OECD Science, Technology, and Industry Working Papers, No. 2018/14. Paris: OECD Publishing.

Cano-Kollmann, M., Awate, S., Hannigan, T. J., \& Mudambi, R. (2018). Burying the hatchet for catch-up: open innovation among industry laggards in the automotive industry. California Management Review, 60(2), 17-42.

Chen, H., Chiang, R. H., \& Storey, V. C. (2012). Business intelligence and analytics: From big data to big impact. MIS Quarterly, 36(4),1165-1188.

De Backer, K., DeStefano, T., Menon, C., \& Suh, J. R. (2018). Industrial robotics and the global organisation of production. OECD Science, Technology and Industry Working Papers, No. 3, Paris: OECD Publishing. 
POST-COMMUNIST ECONOMIES (1463-1377 1465-3958) - Megjelenés alatt

De Loecker, J., \& Eeckhout, J. (2018). Global market power. National Bureau of Economic Research Working Papers, No. 24768.

DESI (2018). Digital Economy and Society Index Report 2018, Integration of Digital Technologies. https://ec.europa.eu/digital-single-market/en/desi

Eisenhardt, K.M. (1989). Building theories from case study research. Academy of Management Review, 14(4), 532-550.

Etzkowitz, H. (2003). Research groups as 'quasi-firms': the invention of the entrepreneurial university. Research Policy, 32(1), 109-121.

European Innovation Scoreboard (2018). https://ec.europa.eu/docsroom/documents/30684

Farkas, B. (2016). Models of capitalism in the European Union: Post-crisis perspectives. London: Palgrave Macmillan.

Farkas, B. (2011). The Central and Eastern European model of capitalism. Post-Communist Economies, 23(1), 15-34.

Ferràs-Hernández, X., Tarrats-Pons, E., \& Arimany-Serrat, N. (2017). Disruption in the automotive industry: A Cambrian moment. Business Horizons, 60(6), 855-863.

Galgóczi, B., Drahokoupil, J., \& Bernaciak, M. (Eds.). (2015). Foreign investment in Eastern and Southern Europe after 2008: Still a lever of growth? Brussels: European Trade Union Institute.

Gao, P., Kaas, H.W., Mohr, D., \& Wee, D. (2016). Disruptive trends that will transform the auto industry. McKinseyReport. https://www.mckinsey.com/industries/automotive-andassembly/our-insights/disruptive-trends-that-will-transform-the-auto-industry

Gawer, A., \& Cusumano, M. A. (2014). Industry platforms and ecosystem innovation. Journal of Product Innovation Management, 31(3), 417-433. 
POST-COMMUNIST ECONOMIES (1463-1377 1465-3958) - Megjelenés alatt

Georgieva, D. P., Loayza, N., \& Mendez Ramos, F. (2018). Global Trade: Slowdown, Factors, and Policies. World Bank Policy Research Working Paper, No. 123899.

Gioia, D. A., Corley, K. G., \& Hamilton, A. L. (2013). Seeking qualitative rigor in inductive research: Notes on the Gioia methodology. Organizational Research Methods, 16(1), 15-31.

Glaser, B. G. (1965). The constant comparative method of qualitative analysis. Social Problems, 12(4), 436-445.

Götz, M. (2019). Attracting Foreign Direct Investment in the Era of Digitally Reshaped International Production. The Primer on the Role of the Investment Policy and Clusters-The Case of Poland. Journal of East-West Business, 26, forthcoming, DOI: 10.1080/10669868.2019.1692985.

Götz, M., \& Jankowska, B. (2017). Clusters and Industry 4.0-do they fit together?. European Planning Studies, 25(9), 1633-1653.

Hallward-Driemeier, M., \& Nayyar, G. (2017). Trouble in the Making?: The Future of Manufacturing-led Development. World Bank Publications.

Hill, K., Menk, D., Swiecki, B., \& Cregger, J. (2014). Just How High-Tech is the Automotive Industry?. Ann Arbor, MI: Center for Automotive Research. https://autoalliance.org/wpcontent/uploads/2017/01/CARReport_Just_How_High_Tech_is_the_Automotive_Industry.pdf Hirsch-Kreinsen, H., \& Schwinge, I. (Eds.). (2014). Knowledge-intensive entrepreneurship in low-tech industries. Cheltenham: Edward Elgar Publishing.

Kagermann, H., Helbig, J., Hellinger, A., \& Wahlster, W. (2013). Recommendations for Implementing the strategic initiative INDUSTRIE 4.0: securing the future of German manufacturing industry; final report of the Industrie 4.0 working group. Forschungsunion. 
Kaiser, C., Stocker, A., \& Viscusi, G. (2017). Digital Vehicle Ecosystems and New Business Models: An Overview of Digitalization Perspectives. Paper prepared for Platform Economy \& Business Models workshop at i-KNOW'17 October 11-12, 2017, Graz.

Kuang, X., Zhao, F., Hao, H., \& Liu, Z. (2018). Intelligent connected vehicles: the industrial practices and impacts on automotive value-chains in China. Asia Pacific Business Review, 24(1), 1-21.

Lee, J., \& Gereffi, G. (2015). Global value chains, rising power firms and economic and social upgrading. Critical Perspectives on International Business, 11(3/4), 319-339.

Lyytinen, K., Yoo, Y., \& Boland Jr, R. J. (2016). Digital product innovation within four classes of innovation networks. Information Systems Journal, 26(1), 47-75.

Majchrzak, A., \& Malhotra, A. (2013). Towards an information systems perspective and research agenda on crowdsourcing for innovation. The Journal of Strategic Information Systems, 22(4), 257-268.

Manyika, J., Chui, M., Bughin, J., Dobbs, R., Bisson, P., \& Marrs, A. (2013). Disruptive technologies: Advances that will transform life, business, and the global economy. San Francisco, CA: McKinsey Global Institute.

Mendonça, S. (2009). Brave old world: Accounting for 'high-tech' knowledge in 'low-tech' industries. Research Policy, 38(3), 470-482.

Monostori, L., Kádár, B., Bauernhans1, T., Kondoh, S., Kumara, S., Reinhart, G., Sauer, O., Schuh, G., Sihn, W., \& Ueda, K. (2016). Cyber-physical systems in manufacturing. CIRP Annals-Manufacturing Technology, 65(2), 621-641.

Nambisan, S. (2017). Digital entrepreneurship: Toward a digital technology perspective of entrepreneurship. Entrepreneurship Theory and Practice, 41(6), 1029-1055. 
Nambisan, S., Lyytinen, K., Majchrzak, A., \& Song, M. (2017). Digital innovation management: Reinventing innovation management research in a digital world. MIS Quarterly, 41(1), 223-238.

Nelson R. R., \& Winter S. G. (1982). An evolutionary theory of economic change, Cambridge: Harvard University Press.

Nölke, A., \& Vliegenthart, A. (2009). Enlarging the varieties of capitalism: The emergence of dependent market economies in East Central Europe. World politics, 61(4), 670-702.

Parrilli, M. D., \& Blažek, J. (2018). Clusters, industrial districts and the impact of their growing intersection with global value chains. In: De Marchi, V., Di Maria, E., \& Gereffi, G. (Eds.) Local clusters in global value chains: linking actors and territories through manufacturing and innovation. New York: Routledge, pp. 51-68.

Patton, M.Q. (1990). Qualitative evaluation and research methods. Newbury Park, CA.: Sage Publications.

Pavlínek, P. (2017). Dependent Growth: Foreign Investment and the Development of the Automotive Industry East-Central Europe. Cham: Springer.

Pavlínek, P., \& Žížalová, P. (2016). Linkages and spillovers in global production networks: firm-level analysis of the Czech automotive industry. Journal of Economic Geography, 16(2), $331-363$.

Porter, M. E. (1990). The competitive advantage of nations. New York: Free Press.

Porter, M. E., \& Heppelmann, J. E. (2014). How smart, connected products are transforming competition. Harvard Business Review, 92(11), 64-88.

Raub, W., Buskens, V., \& Van Assen, M. A. (2011). Micro-macro links and microfoundations in sociology. The Journal of Mathematical Sociology, 35(1-3), 1-25. 
POST-COMMUNIST ECONOMIES (1463-1377 1465-3958) - Megjelenés alatt

Ries, E. (2011). The lean startup: How today's entrepreneurs use continuous innovation to create radically successful business. New York: Crown Business.

Ross, P. K., \& Blumenstein, M. (2015). Cloud computing as a facilitator of SME entrepreneurship. Technology Analysis \& Strategic Management, 27(1), 87-101.

Schwab, K. (2016). The Fourth Industrial Revolution. Geneva: World Economic Forum.

SEP (2019). Tech Scaleup Europe. 2019 Report. Brussels: Mind the Bridge \& Startup Europe Partnership. Available at: https://startupeuropepartnership.eu/wpcontent/uploads/2019/06/2019_TechScaleupEurope.pdf

Simula, H., \& Ahola, T. (2014). A network perspective on idea and innovation crowdsourcing in industrial firms. Industrial Marketing Management, 43(3), 400-408.

Somaya, D., Teece, D., \& Wakeman, S. (2011). Innovation in multi-invention contexts: Mapping solutions to technological and intellectual property complexity. California Management Review, 53(4), 47-79.

Stankovska, I., Josimovski, S., \& Edwards, C. (2016). Digital channels diminish SME barriers: the case of the UK. Economic research-Ekonomska istraživanja, 29(1), 217-232.

Sturgeon, T., Van Biesebroeck, J., \& Gereffi, G. (2008). Value chains, networks and clusters: reframing the global automotive industry. Journal of Economic Geography, 8(3), 297-321.

Sussan, F., \& Acs, Z. J. (2017). The digital entrepreneurial ecosystem. Small Business Economics, 49(1), 55-73.

Szalavetz, A. (2019). Industry 4.0 and capability development in manufacturing subsidiaries. Technological Forecasting and Social Change, 145, 384-395. 
POST-COMMUNIST ECONOMIES (1463-1377 1465-3958) - Megjelenés alatt

Szalavetz, A. (2020). Digital entrepreneurs in factory economies. In: Drahokoupil, J. (Ed.) Digitalization of Industry - Transformation of Production Networks in Europe. (working title). Brussels: European Trade Union Institute, forthcoming.

Szerb, L., Vörös, Zs., Páger, B., Ács, Z. J., \& Komlósi É. (2018). Case Study on the Hungarian New Tech Entrepreneurial Ecosystem. Project FIRES deliverable, Work Package 5.8. http://www.projectfires.eu/wp-content/uploads/2018/02/D5-8-Case-Study-REVISED.pdf

UNCTAD (2018). World Investment Report. Investment and new industrial policies. Geneva:

\section{UNCTAD}

Wiener, A. (2017). Inside Adidas' Robot-Powered, On-Demand Sneaker Factory. Wired Business, 29/11/2017.

Zeid, A., Sundaram, S., Moghaddam, M., Kamarthi, S., \& Marion, T. (2019). Interoperability in Smart Manufacturing: Research Challenges. Machines, 7(2), 21. 
Figure 1. Domestic-owned Hungarian actors in the digital automotive technology

ecosystem

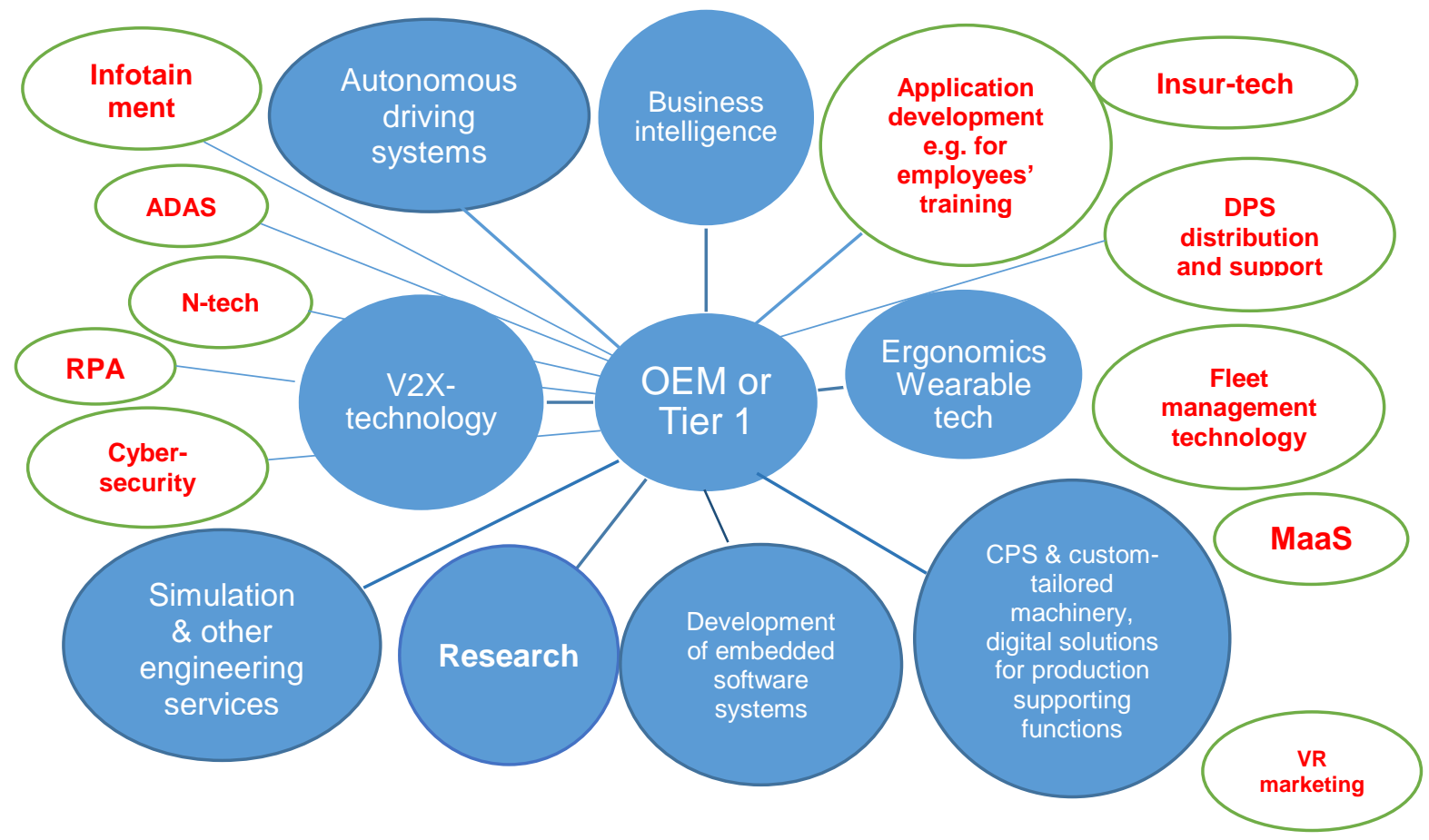

Note: ADAS stands for advanced driver assistance system, CPS for cyber-physical systems, specifically for automotive production related software and hardware solutions, DPS for digital prototyping solution, Insur-tech for smart insurance system relying on embedded telematics technologies, and MaaS for mobility-as-a-service (ride-sharing technology). N-tech denotes navigation technology. RPA refers to robotic process automation, such as AI-powered machine vision quality control, and VR refers to virtual reality applications. The circles are connected to the hypothetical OEM (or Tier 1 supplier) in the middle if the companies representing the given technological area are direct suppliers. If they are simply present in the automotive ecosystem (e.g. Insur-tech or MaaS companies) the circles are not connected. 
Table 1. Overview of sample firm characteristics (data are for 2018)

\begin{tabular}{|c|c|c|c|c|c|}
\hline No. & Product / solution & $€$ & $\begin{array}{c}\text { Employ } \\
\text { ment }\end{array}$ & $\begin{array}{c}\text { Found } \\
\text { ation }\end{array}$ & Interviewee \\
\hline 1 & $\begin{array}{l}\text { A self-driving software stack. } \\
\text { A simulation solution for testing autonomous } \\
\text { vehicles. } \\
\text { A power-efficient solution to accelerate artificial } \\
\text { intelligence-based self-driving software deployment, } \\
\text { and to solve the problems associated with the high } \\
\text { power consumption of the hardware that accelerates } \\
\text { AI-based automated driving solutions. }\end{array}$ & $\sim 5 \mathrm{~m}$ & $182 *$ & 2015 & $\begin{array}{l}\text { marketing } \\
\text { officer }\end{array}$ \\
\hline 2 & $\begin{array}{l}\text { Business intelligence: provision of big data, data } \\
\text { visualization and analytics-based solution of } \\
\text { company-specific problems; data engineering, } \\
\text { strategic consulting relying on data science } \\
\text { approaches. }\end{array}$ & $9.5 \mathrm{~m}$ & 136 & 2006 & $\begin{array}{c}\text { communication } \\
\text { officer }\end{array}$ \\
\hline 3 & $\begin{array}{l}\text { Connected car vehicle-to-everything }(\mathrm{V} 2 \mathrm{X}) \\
\text { solutions: a software stack allowing for V2X } \\
\text { communication to be integrated in on-board units or } \\
\text { roadside units. }\end{array}$ & $\sim 1 \mathrm{~m}$ & 29 & 2012 & $\begin{array}{l}\text { technology } \\
\text { officer }\end{array}$ \\
\hline 4 & $\begin{array}{l}\text { Integrated digital ergonomics system, i.e. a motion } \\
\text { digitizing and evaluating device that captures, } \\
\text { measures, records, and analyses data related to } \\
\text { assembly workers' motion, to be used for ergonomic } \\
\text { analyses and testing. }\end{array}$ & $\sim 7 \mathrm{k}$ & 4 & 2014 & $\begin{array}{l}\text { managing } \\
\text { director }\end{array}$ \\
\hline 5 & $\begin{array}{l}\text { Engineering services for the implementation of } \\
\text { production tracking systems, barcode and RFID } \\
\text { solutions for production logistics and warehousing, } \\
\text { self-developed real-time location system. }\end{array}$ & $3.9 \mathrm{~m}$ & 31 & 1990 & $\begin{array}{l}\text { business unit } \\
\text { manager }\end{array}$ \\
\hline 6 & $\begin{array}{l}\text { Development, manufacturing, deployment and } \\
\text { commissioning of custom-tailored production } \\
\text { machinery combined with smart solutions. } \\
\text { Analysis and solution of specific technological } \\
\text { problems related to customers' product and process } \\
\text { development and engineering activities. } \\
\text { R\&D in the field of simulation methods and finite } \\
\text { element analysis. }\end{array}$ & $7.15 \mathrm{~m}$ & 51 & 2002 & founder \\
\hline 7 & $\begin{array}{l}\text { Engineering services for the development and } \\
\text { deployment of cyber-physical production systems } \\
\text { (CPPS), robotic system integration, development of } \\
\text { CPPS-based functional solutions (e.g. quality control, } \\
\text { process automation, production monitoring and } \\
\text { optimization, etc.). R\&D on collaborative robots, } \\
\text { development of demonstration use cases of } \\
\text { collaborative robots. }\end{array}$ & $5.5 \mathrm{~m}$ & 46 & 1991 & $\begin{array}{l}\text { business } \\
\text { development } \\
\text { manager }\end{array}$ \\
\hline 8 & $\begin{array}{l}\text { Conceptual design and implementation of customized } \\
\text { special-purpose machinery for factory automation; } \\
\text { system integration services (robotics, computer } \\
\text { vision, measurement system, data acquisition and } \\
\text { processing). }\end{array}$ & $\sim 508 \mathrm{k}$ & 14 & 2012 & founder \\
\hline 9 & $\begin{array}{l}\text { Design and implementation of cyber-physical } \\
\text { systems and analytics solutions for manufacturing } \\
\text { companies. Consultancy about the ways and methods } \\
\text { of digital transformation and implementation of smart } \\
\text { factory solutions. Data-driven and AI-powered } \\
\text { business process reengineering and optimization, } \\
\text { solution of technological problems. }\end{array}$ & $67 \mathrm{k}$ & 2 & 2013 & founder \\
\hline
\end{tabular}




\begin{tabular}{|c|l|l|l|l|l|}
\hline 10 & $\begin{array}{l}\text { An industrial Internet of Things (IIoT) platform for } \\
\text { smart factories, based on big data technologies and } \\
\text { machine learning. The platform is capable to } \\
\text { implement machine-learning-powered process } \\
\text { optimization. The platform supports smart factory } \\
\text { applications. Design and implementation of smart } \\
\text { factory solutions on the basis of this platform. }\end{array}$ & $\sim 25 \mathrm{k}$ & 10 & 2017 & founder \\
\hline
\end{tabular}

$€=$ net sales in EUR (the exchange rate used for conversion from HUF was 319)

$\mathrm{k}=$ thousand, $\mathrm{m}=$ million, employment $=$ number of employees, $\mathrm{MES}=$ manufacturing execution system

- Engineering services include assessment of the customer's processes, identification of bottlenecks, conceptual design of a solution, procurement, deployment, installation (commissioning), and in some cases service and maintenance of system-specific hardware e.g. machinery, or track and tracing infrastructure, cameras, sensors, or other data capture tools, user interfaces, and other system components, together with the development and deployment of the related software e.g. reporting algorithms, mobile applications, and system integration services. * In addition to 182 employees in Hungary, the company has dozens of employees abroad. 


\section{Annex}

\section{Table A. Examples illustrating the procedure of data analysis}

\begin{tabular}{|c|c|c|c|}
\hline & $\begin{array}{c}\text { First order data, interviewees' } \\
\text { remarks }\end{array}$ & $2^{\text {nd }}$ order themes & $\begin{array}{c}3^{\text {rd }} \text { order } \\
\text { concepts } \\
\text { (mechanisms) }\end{array}$ \\
\hline \multirow{3}{*}{$\begin{array}{l}\text { Examples } \\
\text { of } \\
\text { remarks } \\
\text { related to } \\
\text { profile }\end{array}$} & $\begin{array}{l}\text { "Our traceability solution is part of a hugely } \\
\text { complex system. In smart factories dozens } \\
\text { of smart solutions (manufacturing modules) } \\
\text { are integrated that, together, contribute to } \\
\text { improved resource efficiency and } \\
\text { operational excellence. Customers often rely } \\
\text { on multiple vendors." }\end{array}$ & \multirow{2}{*}{$\begin{array}{l}\text { Digital } \\
\text { transformation is the } \\
\text { result of a great } \\
\text { number of projects: } \\
\text { individual solutions } \\
\text { are interconnected, } \\
\text { albeit often deployed } \\
\text { sequentially and } \\
\text { modularly. }\end{array}$} & \multirow{3}{*}{$\begin{array}{l}\text { A multiplicity of } \\
\text { entrepreneurial } \\
\text { opportunities } \\
\text { involving } \\
\text { knowledge- } \\
\text { intensive, digital } \\
\text { services } \\
\text { provision } \\
\text { Fine-slicing } \\
\text { innovation }\end{array}$} \\
\hline & $\begin{array}{l}\text { "The term 'engineering' cannot truly reflect } \\
\text { how heterogeneous our assignments are. We } \\
\text { specialize in simulation-driven product } \\
\text { development and finite element analysis, } \\
\text { perform technical calculations for } \\
\text { optimization, provide system integration } \\
\text { services, and design special purpose } \\
\text { machines, among others. Every project } \\
\text { involves a set of different knowledge- } \\
\text { intensive tasks. Sometimes this requires } \\
\text { collaboration with our usual partners } \\
\text { providing specialized expertise." }\end{array}$ & & \\
\hline & $\begin{array}{l}\text { "This 'breakthrough invention' is in fact } \\
\text { only a tiny part of the whole complex smart } \\
\text { system." }\end{array}$ & $\begin{array}{l}\text { A complex } \\
\text { technology stack } \\
\text { consisting of multiple } \\
\text { specific knowledge } \\
\text { components. }\end{array}$ & \\
\hline \multirow{6}{*}{$\begin{array}{l}\text { Examples } \\
\text { of } \\
\text { remarks } \\
\text { related to } \\
\text { market } \\
\text { orientation } \\
\text { and } \\
\text { business } \\
\text { developme } \\
\text { nt strategy }\end{array}$} & $\begin{array}{l}\text { "It would be prohibitively expensive for } \\
\text { them [customers] to finance several man- } \\
\text { months of German engineers, while they } \\
\text { fine-tune the solution." }\end{array}$ & \multirow{2}{*}{$\begin{array}{l}\text { Custom-tailored } \\
\text { solutions address } \\
\text { firm-specific } \\
\text { problems. } \\
\text { Local procurement of } \\
\text { digital services }\end{array}$} & $\begin{array}{l}\text { Ecosystem-type } \\
\text { innovation } \\
\text { collaboration }\end{array}$ \\
\hline & $\begin{array}{l}\text { "We don't receive 'ready use cases': we } \\
\text { have to explore and understand the processes } \\
\text { first, then we jointly define the problems and } \\
\text { the indicators that will measure the solution } \\
\text { of these problems. This is the process when } \\
\text { several skeletons fall out of the cupboard." }\end{array}$ & & $\begin{array}{l}\text { Interaction- } \\
\text { intensity of } \\
\text { digital services } \\
\text { provision }\end{array}$ \\
\hline & $\begin{array}{l}\text { "We have a broader set of business } \\
\text { partners." }\end{array}$ & \multirow{4}{*}{$\begin{array}{l}\text { An ecosystem of } \\
\text { collaborating actors, } \\
\text { innovation } \\
\text { collaboration; } \\
\text { decentralized, open } \\
\text { innovation }\end{array}$} & \\
\hline & $\begin{array}{l}\text { "They would help us seize new business } \\
\text { opportunities." }\end{array}$ & & \\
\hline & "We are part of their business community." & & \\
\hline & "It's a kind of joint value creation." & & \\
\hline
\end{tabular}

\section{NOTES}

\footnotetext{
${ }^{1}$ According to Baldwin's (2013) categorisation, in international production networks there are 'headquarter economies' where economic actors mainly govern the production networks (and carry out business development and other intangible, headquarter-specific activities), and 'factory economies' that provide the labour, i.e. they perform predominantly labour-intensive activities.
} 
${ }^{2}$ The cascade effect is a process in which the orchestrators of global value chains specialize in even higher value generating activities than previously. To do so, in a context of limited capacities, they delegate some relatively advanced activities to lower-tier GVC participants. In turn, when these suppliers take up these high(er)-value activities, they also relinquish some relatively advanced functions to even lower-tier GVC participants.

${ }^{3}$ This is in line with the evolutionary view of technological development (Nelson and Winter, 1982) maintaining that technological change induces selection, retention and reconfiguration mechanisms.

${ }^{4}$ The business digitization index is a sub-index of the composite Digital Economy and Society Index. It measures the diffusion of electronic information sharing, cloud computing, and RFID technologies across business enterprises, as well as the incidence of eInvoices and corporate social media solutions.

${ }^{5}$ Szerb et al. (2018) provide a detailed overview of the state of affairs of Hungary's digital entrepreneurship performance.

${ }^{6}$ Hungary scored $50^{\text {th }}$ in the 2018 edition of the Global Entrepreneurship and Development Index. By contrast, Poland scored $30^{\text {th }}$, Slovakia: $36^{\text {th }}$, and the Czech Republic: $38^{\text {th }}$ (Ács et al., 2018, pp. 28-29.).

${ }^{7}$ According to the results of the survey using the newly created European Index of Digital Entrepreneurship Systems, Hungary ranks $24^{\text {th }}$ among EU28 (Autio et al., 2018b).

8 Data for the share of the transport equipment industry in manufacturing employment and in total manufacturing export are available only for 2017: $16.9 \%$ and $35.5 \%$ respectively. Source: Author's calculations from Central Statistical Office data.

${ }^{9}$ Drawing on Gawer and Cusumano, (2014), I define platforms as products, services, or technologies (hardware and/or software) that serve as ground infrastructure upon which additional firms can build further complementary innovations and potentially generate network effects.

${ }^{10}$ In selected areas, we could identify several companies. One area where numerous notable domestic-owned digital entrepreneurs are represented is the provision of industry 4.0 solutions for manufacturing companies, that is, development and deployment of cyber-physical systems, provision of system integration services, industrial automation, and development of various digital solutions supporting production-related business functions.

${ }^{11}$ One exception is development of industrial design software, referred to as digital prototyping solution, (DPS). DPS is a solution used for virtual product or component design (testing, simulation, and generative design). DPS solutions, used in the automotive industry, had been developed by large global firms, not by Hungarian domestic-owned ones. However, these firms have several domestic-owned distributors of their solutions in Hungary. Local distributors provide knowledge-intensive support services to Hungary-based automotive industry suppliers, subscribers to the given solution. Another exception is a notable navigation technology company (that has solutions also in the field of infotainment and automotive cyber security). Originally a Hungarian start-up, this company does not count as domestic-owned any more, since it was acquired several years ago by a foreign company.

${ }^{12}$ Virtual commissioning refers to 3D simulation of any interventions in a production plant, production line, or work cell. The proposed changes or expansion can thus be tested and validated in the virtual environment (in the digital twin model), before implemented in reality. ${ }^{13}$ According to the 2019 Report of Startup Europe Partnership on tech scale-ups in Europe (SEP, 2019) the number of technology scale-ups, i.e. start-ups that managed to "break the earlystage barrier", grow, and receive more than USD 1 million funding for their expansion, was 39 in Hungary. For the sake of comparison, the respective number was 2,217 in the UK, 649 in Germany, 79 in Austria, 78 in Poland, and 60 in Estonia. The report considered only technology and digital companies excluding pharma, biotech, life sciences and semiconductors. 
${ }^{14}$ Example of product-embedded solutions offered by the surveyed companies include the selfdriving technology, the navigation technology, and the connected car technology. Example of (automotive) product-related digital solutions are mobility-as-a-service technology, telematicsbased insurance technology, and the virtual marketing solution.

15 Nambisan (2017, p. 1031) defines digital artifacts as a "digital component, application, or media content that is part of a new product (or service) and offers a specific functionality or value to the end-user." 